\title{
GMR
}

\section{Genetic variability analysis of Byrsonima crassifolia germplasm collected in Pará State using ISSR markers}

S.M. Rodrigues ${ }^{1}$, E.F. Moura ${ }^{1}$, G.K.S. Ramos ${ }^{2}$ and M.S.P. Oliveira ${ }^{1}$

${ }^{1}$ Laboratório de Genética Molecular, Embrapa Amazônia Oriental, Belém, PA, Brasil

${ }^{2}$ Universidade Federal Rural da Amazônia, Belém, PA, Brasil

Corresponding author: S.M. Rodrigues

E-mail: simone.rodrigues@embrapa.br

Genet. Mol. Res. 15 (4): gmr15048887

Received June 16, 2016

Accepted July 20, 2016

Published October 17, 2016

DOI http://dx.doi.org/10.4238/gmr15048887

Copyright (C) 2016 The Authors. This is an open-access article distributed under the terms of the Creative Commons Attribution ShareAlike (CC BY-SA) 4.0 License.

\begin{abstract}
Native of the Amazon, the nanche (Byrsonima crassifolia) is a fruit cultivated by family farmers and used in cooking; as such, it represents an opportunity for regional agribusiness. The Embrapa Eastern Amazon set up an active germplasm bank (BAG) consisting of 22 accessions sampled in 11 municipalities of Pará State. Due to its economic potential, there is an interest to advance the genetic breeding program of this species. The aim of this study was to characterize the BAG nanche collection using inter-simple sequence repeat (ISSR) markers. Accessions were genotyped using 23 preselected ISSR primers resulting in 109 amplified polymorphic and 51 monomorphic bands. With eight polymorphic bands each, the most polymorphic primers were UBC 809 and UBC 848. An unweighted pair-group method with arithmetic average cluster analysis based on Jaccard's coefficient indicated that the individuals clustered into two
\end{abstract}


distinct groups. Accessions Igarapé Açu-2 and Augusto Corrêa-Pl 1 were most similar. The genetic dissimilarity values ranged from 0.10 to 0.59 . We conclude that the ISSR markers were efficient in detecting polymorphisms in the nanche accessions, and that it is possible to infer the genetic variability among accessions of the collection. This demonstrate the importance of using molecular markers in poorly studied species and the advantages that this information can bring to the genetic improvement of such species.

Key words: Malpighiaceae; Molecular markers; Muruci; Semi-domesticated species

\section{INTRODUCTION}

Nanche (Byrsonima crassifolia (L.) H.B.K.) is considered a semi-domesticated shrub species native of the Amazon and widely distributed in tropical America (Cavalcante, 2010). It is the most important fruit crop of the genus Byrsonima and the most cultivated, since it produces fleshy fruits used in cooking, as well as for making sweets and liqueurs (Cavalcante, 2010; Carvalho and Nascimento, 2013). This species is rich in polyphenols and flavonoid compounds that provide antioxidants. Nanche is therefore considered a functional food (Silva et al., 2007; Souza et al., 2008). It is considered an allogamous plant with auto-compatibility (Sihag, 1995), although low formation of fruits has been observed in self-pollination experiments (Pereira and Freitas, 2002). Cultivation of this species presents an opportunity for diversification in local production structures, expanding the availability of agribusiness products in the Amazon region. It is typically grown by family farmers, has a guaranteed consumer market, and can be produced on a commercial scale due to the development of propagation methods that accelerate and standardize the seed germination (Carvalho and Nascimento, 2008).

The Embrapa Eastern Amazon has assembled an active germplasm bank (BAG) of nanche germplasms and identified promising materials for breeding purposes (Carvalho and Nascimento, 2013). Further experimental evaluations of this germplasm may allow for recommendations of appropriate and stable cultivars for producing regions. Thus, due to this species' potential, it is necessary to realize a large-scale study of the BAG, which conserves accessions from places of origin of this species. Knowledge about the available germplasm bank can enable traceability and the rescue of accessions by identifying potential replacements in case of loss of plants. Furthermore, the collection may be enriched and kept in order, to preserve its genetic variability (Borém and Miranda, 2013). In addition, the knowledge of the genetic variability of the conserved accessions is indispensable for the development of genetic breeding programs.

Molecular markers have been used in genetic diversity studies in plant species, to determine the variation in collections and germplasm banks, to direct crosses, and to identify markers that describe plant materials and recommended cultivars (Ferreira and Grattapaglia, 1998). Despite the economic importance of B. crassifolia, there are few studies using molecular markers in this species. Inter-simple sequence repeats (ISSRs) are dominant and represent genetic variation within microsatellite regions in the genome. They have been used to estimate genetic diversity and genetic parameters of populations of multiple plant species (Rivas et al., 2013; Lorenzoni et al., 2014; Rossi et al., 2014; Silva et al., 2014; Ghariani et al., 2015; ArrigoniBlank et al., 2016; Shen et al., 2016). The advantage of ISSRs is the possibility to obtain a high

Genetics and Molecular Research 15 (4): gmr15048887 
number of polymorphic loci without the need of genome sequence knowledge (Faleiro, 2007).

The aim of this study was to verify the genetic variability of $B$. crassifolia accessions from the Embrapa Eastern Amazon germplasm bank, using ISSR markers focusing on the identification of superior materials for conventional genetic improvement.

\section{MATERIAL AND METHODS}

\section{Plant material}

A total of 22 accessions of $B$. crassifolia were used in this study (Table 1). The accessions were collected in 11 cities of the Pará State (Figure 1), and are conserved as clones at the Embrapa Eastern Amazon germplasm bank (Table 1).

Table 1. Origin of nanche (Byrsonima crassifolia) accessions used in this study collected from the Pará State and belonging to the Eastern Amazon germplasm bank.

\begin{tabular}{l|l}
\hline Accession & Collection site \\
\hline 1 - Açu (AÇU) & Tomé Açu \\
\hline 2 - Santarém-1 (SANT-1) & Santarém \\
\hline 3 - Santarém-2 (SANT-2) & Santarém \\
\hline 4 - Igarapé Açu-1 (IG.AÇU-1) & Igarapé Açu \\
\hline 5 - Tocantins-2 (TO-2) & Nova Ipixuna \\
\hline 6 - Cristo & Belém \\
\hline 7 - Maracanã-2 (MARAC-2) & Maracanã \\
\hline 8 - Guataçara 1.1 (GUAT 1-1) & Terra Alta \\
\hline 9 - Tocantins-1 (TO-1) & Nova Ipixuna \\
\hline 10 - São José (S. JOSÉ) & Igarapé Açu \\
\hline 11 - Aurora 1 (AUR 1) & Aurora do Pará \\
\hline 12 - FCAP-7 & Belém \\
\hline 13 - Baião-2 & Baião \\
\hline 14 - Augusto Corrêa-P1 1 (AC 1) & Augusto Corrêa \\
\hline 15 - Augusto Corrêa-P1 2(AC 2) & Augusto Corrêa \\
\hline 16 - Kishi-3 & Monte alegre \\
\hline 17 - Igarapé Açu-2 (IG.AÇU-2) & Igarapé Açu \\
\hline 18 - Igarapé Açu-3 (IG.AÇU-3) & Igarapé Açu \\
\hline 19 - Igarapé Açu-4 (IG.AÇU-4) & Igarapé Açu \\
\hline 20 - Unnamed (UN) & Unknown origin \\
\hline 21 - Aurora-2 (AUR 2) & Aurora do Pará \\
\hline 22 - Xininga-5 (XIN-5) & Baião \\
\hline & \\
\hline
\end{tabular}

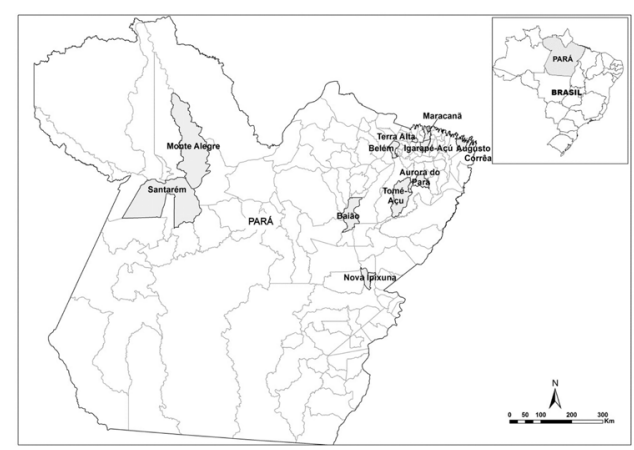

Figure 1. Map showing the collection sites of 22 accessions of nanche (Byrsonima crassifolia) in 11 municipalities in Pará State that were characterized with ISSR markers.

Genetics and Molecular Research 15 (4): gmr15048887 


\section{DNA analyses}

Leaves were sampled from the accessions and total genomic DNA was extracted according to a procedure similar to that of Doyle and Doyle (1990). The tissue was macerated with liquid nitrogen and polyvinylpyrrolidone (PVP). Subsequently, $3 \mathrm{~mL}$ cetyltrimethylammonium bromide $(\mathrm{CTAB})$ extraction buffer $(2 \% \mathrm{CTAB}, 5 \mathrm{M} \mathrm{NaCl}$, $0.5 \mathrm{M}$ EDTA, PVP, $1 \mathrm{M}$ Tris-HCl, and sterile water) were added to the macerate. The macerate was homogenized and incubated in hot water bath at $65^{\circ} \mathrm{C}$ for $1 \mathrm{~h}$. Following this, chloroform:isoamyl alcohol (24:1) was added followed by homogenization, and the samples were centrifuged for $10 \mathrm{~min}$ at $11,952 \mathrm{~g}$. To precipitate the DNA, $3 \mathrm{~mL} 95 \%$ ethyl alcohol was added to the supernatant and the samples were centrifuged for 10 min at 11,952 $\mathrm{g}$. Next, the precipitate was washed with $70 \%$ ethyl alcohol for $10 \mathrm{~min}$ and centrifuged at $2991 \mathrm{~g}$. DNA samples were resuspended in $300 \mu \mathrm{L}$ TE buffer $(10 \mathrm{mM}$ Tris-HCl, $1 \mathrm{mM}$ EDTA, $\mathrm{pH}$ 8.0) and RNAse. DNA was quantified on a $1 \%$ agarose gel, using lambda phage DNA as a standard, at different concentrations (50, 100, and $200 \mathrm{ng} / \mu \mathrm{L})$.

The samples were genotyped using 23 ISSR primers (University of British Columbia, Vancouver, Canada) that had been identified after the primer selection phase, using DNA from five B. crassifolia accessions from the Embrapa Eastern Amazon BAG. A polymerase chain reaction was performed using a final volume of $20 \mu \mathrm{L}$, containing 10 ng genomic DNA, $75 \mu \mathrm{M}$ each dNTP, $2.0 \mu \mathrm{M}$ primer, $1.0 \mathrm{mg} / \mathrm{mL}$ bovine serum albumin, and reaction buffer containing $1.2 \mathrm{mM} \mathrm{MgCl}$ and $0.2 \mathrm{U}$ Taq DNA polymerase (Applied Biosystems, Carlsbad, CA, USA). For this step, we tested 100 ISSR primers (UBC 801-900), and the reactions were carried out in 0.2-mL microtubes and amplified on an Amplitherm TX96 thermocycler programmed for 35 cycles. First, there was a denaturation phase at $95^{\circ} \mathrm{C}$ for $5 \mathrm{~min}$. Then, each cycle consisted of DNA denaturation at $95^{\circ} \mathrm{C}$ for 1 min, primer annealing at temperatures ranging from 50 to $62^{\circ} \mathrm{C}$ (depending on the primer, Table 2) for $45 \mathrm{~s}$, and elongation at $72^{\circ} \mathrm{C}$ for $2 \mathrm{~min}$. Following the 35 cycles, there was the final extension at $72^{\circ} \mathrm{C}$ for $5 \mathrm{~min}$. The reaction products were run on a $1.5 \%$ agarose gel (Thermo Fisher Scientific, Boston, MA, USA) prepared with 1.0X TBE buffer $(0.45$ $\mathrm{M}$ Tris-borate and $0.01 \mathrm{M}$ EDTA). Gels were run in a horizontal electrophoresis unit containing 1.0X TBE at a constant voltage of $80 \mathrm{~V}$, were visualized on an ultraviolet light transilluminator (UVB transilluminator, Loccus, LTB-20x20 HE), and images were digitally captured. The fragments were compared with a 1-Kb DNA ladder marker (Applied Biosystems). The annealing temperatures for each primer were chosen according to the result of the reaction that offered the best band sharpness and intensity on the agarose gel for each primer evaluated, and the ability of discrimination of polymorphic bands. The primers were chosen based on their polymorphism.

\section{Data analyses}

The data obtained from the analysis of amplified bands using the 23 primers according to the quality of the polymorphic bands visualized on the gel. Bands with the same run pattern were considered to be the same locus. Presence of a band was scored as (1) and band absence as $(0)$, generating a binary matrix. Only polymorphic bands were analyzed.

The matrix of genetic similarity was generated using PAST (Hammer et al., 2001), based on Jaccard's coefficient: 


$$
s g_{i j}=\frac{a}{a+b+c}
$$

where $a$ is the number of events where the band occurs in both genotypes; $b$ is the number of events where the band occurs only in genotype $i$; and $c$ is the number of events where the band occurs only in genotype $j$.

Table 2. Pre-selection of ISSR primers used in the molecular characterization of nanche (Byrsonima
crassifolia) accessions collected in Pará State.
\begin{tabular}{|c|c|c|c}
\hline Primer & No. of polymorphic bands & Primer & No. of polymorphic bands \\
\hline 808 & 5 & 844 & 3 \\
\hline 809 & 4 & 845 & 5 \\
\hline 811 & 5 & 846 & 6 \\
\hline 812 & 5 & 848 & 6 \\
\hline 813 & 4 & 850 & 4 \\
\hline 814 & 5 & 855 & 4 \\
\hline 815 & 2 & 856 & 6 \\
\hline 825 & 5 & 857 & 3 \\
\hline 826 & 4 & 858 & 5 \\
\hline 835 & 6 & 888 & 4 \\
\hline 836 & 4 & 889 & \\
\hline 843 & 4 & & \\
\hline
\end{tabular}

Total polymorphic bands $=103$. The number of polymorphic bands shown had an annealing temperature of $47^{\circ} \mathrm{C}$.

Based on the genetic similarity matrix, a dendrogram was generated using the unweighted pair group method with arithmetic mean (UPGMA). The relationship between the similarity matrix and the dendrogram was estimated using the coefficient of cophenetic correlation (CCC), according to Sokal and Rohlf (1962).

The assignment of genotypes to groups and relatedness among groups were assessed using STRUCTURE v. 2.3.3 (Pritchard et al., 2000). Admixture and correlated allele models without prior population information were used. Following a burn-in period of 100,000 iterations, ten independent runs were carried out for each number of clusters (K, from 1 to 10), each with 100,000 iterations. The choice of the most likely $\mathrm{K}$ was carried out by calculating the $\Delta \mathrm{K}$ statistic. This statistic is based on the rate of change in the log probability of the data among successive $\mathrm{K}$ values. The selection was done as described by Evanno et al. (2005), using STRUCTURE HARVESTER (Earl and VonHoldt, 2012). Among the 10 runs per value of K, the run with the highest maximum likelihood was used to assign individual genotypes to clusters. STRUCTURE uses a Bayesian approach and indicates the number of genetic groups (K value) that best fits the data

\section{RESULTS}

The pre-selection result of primers indicated polymorphisms in 23 ISSR using an annealing temperature of $47^{\circ} \mathrm{C}$. These primers showed an average polymorphism of 4.4 bands per primer. We noted that some primers resulted in fewer bands using the annealing temperature of $47^{\circ} \mathrm{C}$, compared to DNA amplification using higher annealing temperatures. This was observed using primers UBC 809, UBC 835, UBC 845, UBC 846, UBC 848, and UBC 850. No polymorphism was observed in 77 primers for the five clones evaluated at a temperature of $47^{\circ} \mathrm{C}$. The 23 polymorphic primers were used for the characterization of $B$. crassifolia accessions from the Embrapa Eastern Amazon. 
The 23 selected primers had an average annealing temperature of $52.43^{\circ} \mathrm{C}$. The highest annealing temperature used was $60^{\circ} \mathrm{C}$, which was used for UBC 888 and UBC 889 , whereas the lowest annealing temperature $\left(47^{\circ} \mathrm{C}\right)$ was used for UBC 848 and UBC 850 (Table 3). The annealing temperature of $53^{\circ} \mathrm{C}$ showed the highest amplification quality for the largest number of primers (UBC 811, UBC 813, UBC 843, UBC 855, UBC 857, and UBC 858), followed by $52^{\circ} \mathrm{C}$ annealing temperature, which was optimal for five primers (UBC 825, UBC 826, UBC 835 , UBC 846 , and UBC 856 ). Only the ISSR-845 primer obtained satisfactory amplification products at the $48^{\circ} \mathrm{C}$ annealing temperature.

Table 3. Ideal annealing temperature, number of polymorphic bands, and percent polymorphism for the selected ISSR primers used in the molecular characterization of nanche (Byrsonima crassifolia) accessions collected in Pará State.

\begin{tabular}{|c|c|c|c|c|c|}
\hline Primer & $5^{\prime}$ to $3^{\prime}$ sequence & Annealing temperature $\left({ }^{\circ} \mathrm{C}\right)$ & No. of bands & No. of polymorphic bands & Polymorphism (\%) \\
\hline 808 & $(\mathrm{AG})_{8} \mathrm{C}$ & 50 & 7 & 5 & 71.43 \\
\hline 809 & $(\mathrm{AG})_{8} \mathrm{G}$ & 57 & 11 & 8 & 72.73 \\
\hline 811 & $(\mathrm{GA})_{8} \mathrm{C}$ & 53 & 9 & 5 & 55.56 \\
\hline 812 & $(\mathrm{GA})_{8} \mathrm{~A}$ & 49 & 7 & 5 & 71.43 \\
\hline 813 & $(\mathrm{CT})_{8} \mathrm{~T}$ & 53 & 6 & 4 & 66.67 \\
\hline 814 & $(\mathrm{CT})_{8} \mathrm{~A}$ & 49 & 7 & 5 & 71.43 \\
\hline 815 & $(\mathrm{CT})_{8} \mathrm{G}$ & 49 & 3 & 2 & 66.67 \\
\hline 825 & $(\mathrm{AC})_{8} \mathrm{~T}$ & 52 & 7 & 5 & 71.43 \\
\hline 826 & $(\mathrm{AC})_{8} \mathrm{C}$ & 52 & 6 & 4 & 66.67 \\
\hline 835 & $(\mathrm{AG})_{8} \mathrm{YC}$ & 52 & 4 & 2 & 50.00 \\
\hline 836 & $(\mathrm{AG})_{8} \mathrm{YA}$ & 56 & 7 & 5 & 71.43 \\
\hline 843 & $(\mathrm{CT})_{8} \mathrm{RA}$ & 53 & 5 & 4 & 80.00 \\
\hline 844 & $(\mathrm{CT})_{8} \mathrm{RC}$ & 56 & 5 & 3 & 60.00 \\
\hline 845 & $(\mathrm{CT})_{8} \mathrm{RG}$ & 48 & 10 & 7 & 70.00 \\
\hline 846 & $(\mathrm{CA})_{8} \mathrm{RT}$ & 52 & 7 & 5 & 71.43 \\
\hline 848 & $(\mathrm{CA})_{8} \mathrm{RG}$ & 47 & 12 & 8 & 66.67 \\
\hline 850 & $(\mathrm{GT})_{8} \mathrm{YG}$ & 47 & 9 & 6 & 66.67 \\
\hline 855 & $(\mathrm{GT})_{8} \mathrm{YT}$ & 53 & 6 & 4 & 66.67 \\
\hline 856 & $(\mathrm{AC})_{8} \mathrm{YA}$ & 52 & 5 & 4 & 80.00 \\
\hline 857 & $(\mathrm{AC})_{8} \mathrm{YG}$ & 53 & 8 & 6 & 75.00 \\
\hline 858 & $(\mathrm{TG})_{8} \mathrm{RT}$ & 53 & 4 & 3 & 75.00 \\
\hline 888 & $\mathrm{BDB}(\mathrm{CA})_{7}$ & 60 & 8 & 5 & 62.50 \\
\hline 889 & $\mathrm{DBD}(\mathrm{AC})_{7}$ & 60 & 7 & 4 & 57.14 \\
\hline Total & & Mean $=52.43$ & 160 & 109 & Mean $=68.125$ \\
\hline
\end{tabular}

B: A, G, T; Y: C, T; R: A, G; D: A, G, T.

After the first evaluation, the 23 primers were selected and revealed variation in the number of amplified fragments, totaling 160 DNA fragments. We were able to identify 109 polymorphic bands (Table 3), with an average of 4.74 markers per ISSR primer and $68.13 \%$ polymorphism. The number of polymorphic bands per primer varied from two (UBC 815) to eight (UBC 809 and UBC 848), and the polymorphism ranged from 50 (UBC 835) to 80\% (UBC 843 and UBC 856).

The values of genetic dissimilarities based on Jaccard's coefficient, varied from 0.10 to 0.59 , with an average of 0.33 (Figure 2A). The mean among individual genetic similarity was $30.0 \%$ with an average standard deviation of 0.08 . Most combinations were found in the range of 0.199-0.296, whereas only three combinations were found in the range of 0.494-0.59 (Figure 2B).

Based on the analysis of genetic similarity, the individuals could be allocated to groups (Figure 3). The highest genetic similarity was detected among an accession from Igarapé Açu (Igarapé Açu-2) and one from Augusto Corrêa (Augusto Corrêa-2), whereas the most divergent accessions were Nova Ipixuna (Tocantins-2) and Igarapé Açu (São José) (Figure 3). The dendrogram based on the UPGMA method and Jaccard's genetic similarities among the 22 accessions indicated the formation of one group of individuals collected in the northeast

Genetics and Molecular Research 15 (4): gmr15048887 
of Pará, and another group of individuals containing accessions mainly from southern and western Pará. However, Baião-2 and Xininga-5, collected in the northeast region of the state, were grouped in the latter group, and the accession Tocantins-2 did not cluster with any other accession (Figure 3).

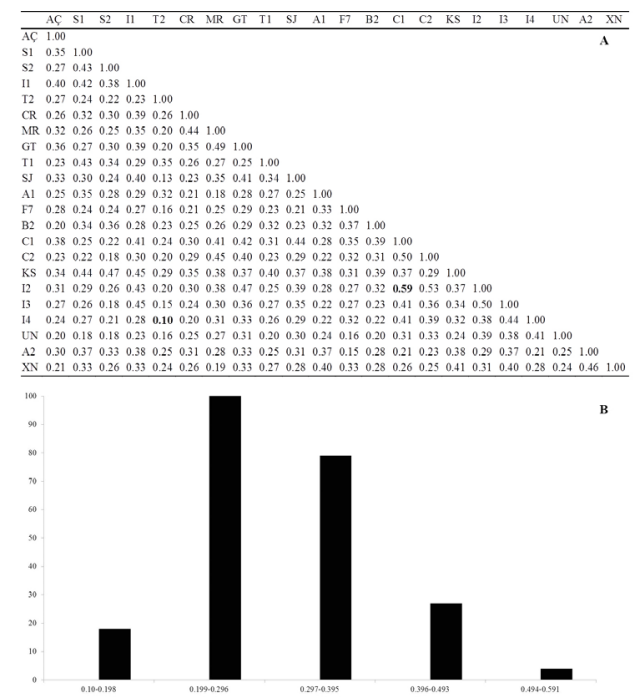

Figure 2. Analysis of genetic identity between accessions of Byrsonima crassifolia, obtained by ISSR markers. A. Matrix of genetic identity. Maximum and minimum values are shown in bold face. AÇ: AÇU; S1: SANT-1; S2: SANT-2; I1: IG.AÇU-1; T2: TO-2; CR: CRISTO; MR: MARAC-2; GT: GUAT 1.1; T1: TO-1; SJ: S. JOSÉ; A1: AUR 1; F7: FCAP-7; B2: BAIÃO-2; C1: AC 1; C2: AC 2; KS: KISHI-3; I2: IG.AÇU-2; I3: IG.AÇU-3; I4: IG.AÇU-4; UN: UN; A2: AUR 2; XN: XIN-5. B. Distribution of genetic identity among accessions.

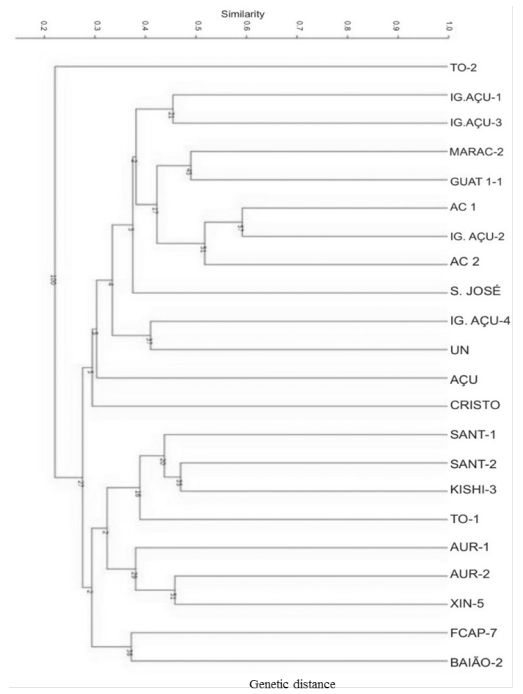

Figure 3. Dendrogram representing the genetic dissimilarity between 22 Byrsonima crassifolia accessions collected in Pará State obtained using the UPGMA method and the arithmetic complement of Jaccard's index as a measure of dissimilarity. The analysis was based on ISSR molecular characterization. Bootstrap values are shown.

Genetics and Molecular Research 15 (4): gmr15048887 
The analysis based on the dendrogram confirmed a clustering concordant with the accessions' geographic origin. However, the sample FCAP-7, from Belém, was closer to Baião-2 (Baião locality). The sample of unknown origin (UN) clustered with a sample from Igarapé Açu, while the accession collected in Tomé Açu (AÇU) was genetically distant from all other individuals of the collection. The result of the cophenetic correlation analysis showed a $72 \%$ association between the distances obtained using the Jaccard coefficient (the dissimilarity matrix) and the dendrogram (the cophenetic matrix). Cruz and Carneiro (2003) stated that the higher the CCC value, the smaller the distortion caused by grouping individuals using the UPGMA. The CCC value was considered appropriate, since values of $r \geq 0.56$ are considered ideal, which reflects a good agreement with the values' genetic similarity (Patto et al., 2004).

The STRUCTURE analysis resulted in the highest $\Delta \mathrm{K}$ value for $\mathrm{K}=2$, in addition to a few other suboptimal $\mathrm{K}$ values (Figure 4A). This suggests that there are two genetically homogeneous accession groups. The structure bar plot shown in Figure 4B also shows two distinct groups.
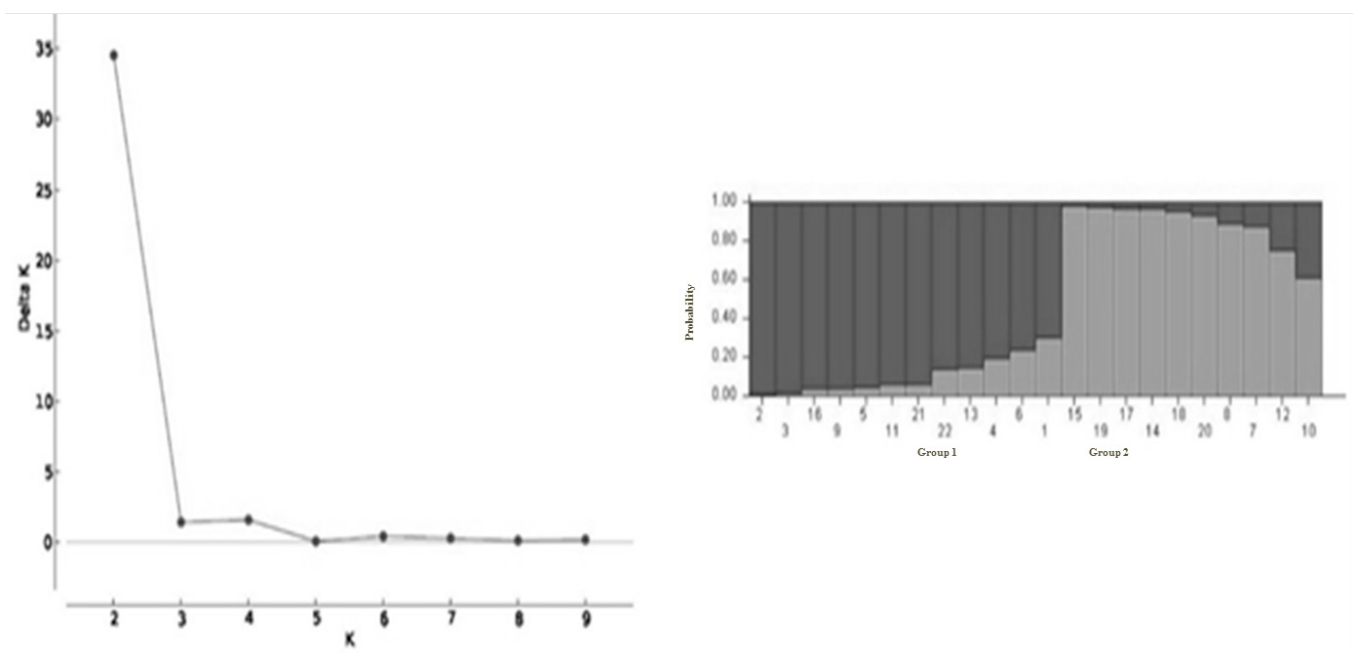

Figure 4. $\triangle \mathrm{K}$ analysis using STRUCTURE (Pritchard et al., 2000) based on ISSR data of 22 Byrsonima crassifolia accessions. A. Indication of the optimal group number present in the sample $(\mathrm{K}=2)$ as determined by the method of Evanno et al. (2005). B. Structure bar plot illustrating the two genetic groups identified by the analysis. Accessions numbers are represented by vertical colored lines. Dark gray columns correspond to group 1 and light gray columns represents group 2. 1: AÇU; 2: SANT-1; 3: SANT-2; 4: IG.AÇU-1; 5: TO-2; 6: CRISTO; 7: MARAC-2; 8: GUAT 1.1; 9: TO-1; 10: S. JOSÉ; 11: AUR 1; 12: FCAP-7; 13: BAIÃO-2; 14: AC 1; 15: AC 2; 16: KISHI-3; 17: IG.AÇU-2; 18: IG.AÇU-3; 19: IG.AÇU-4; 20: UN; 21: AUR 2; 22: XIN-5.

\section{DISCUSSION}

B. crassifolia is considered a semi-domesticated plant and need of additional attention. Advancing the genetic breeding programs of the species may be achieved using molecular markers. Our evaluation of nanche accessions of the Embrapa Eastern Amazon BAG using ISSR markers revealed the need to identify specific temperatures for each of the primers used, as has previously been observed in other species (Pessoni, 2007; Souza et al., 2013; Pepineli et al., 2014). In a similar study conducted for Platonia insignis, 72 genotypes from the Embrapa 
Mid-North germplasm collection were evaluated using 18 primers. An average of 13 loci per primer was identified (Souza et al., 2013). Among the primers used, seven primers (UBC 811, UBC 825, UBC 826, UBC 855, UBC 856, UBC 888, and UBC 890) were also used in the current study. However, different annealing temperatures were used for $P$. insignis (Souza et al., 2013).

In the present study, 160 bands were amplified, resulting in an average of 7.0 loci per primer. The cashew germplasm collection of Embrapa Tropical Agroindustry, consisting of 91 samples, was characterized using 11 polymorphic primers (Pessoni, 2007). UBC 812 was analyzed on a polyacrylamide gel and $92.30 \%$ polymorphic bands were identified (Pessoni, 2007). In the present study, UBC 812 resulted in $71.43 \%$ polymorphic bands. There are several studies in the literature using dominant markers (Carvalho et al., 2012; Lorenzoni et al., 2014), including ISSRs, that consider the percentage polymorphic loci a genetic diversity measure.

Martínez et al. (2013) analyzed B. crassifolia trees found in two different locations in the state of Tabasco, Mexico, using six random amplification of polymorphic DNA (RAPD) primers, three of which were polymorphic. The within-population genetic diversity was higher $(85.20 \%)$ than the between-population genetic diversity $(14.80 \%)$, and it was concluded that dominant markers may be considered useful for identifying genetic variation of this species (Martínez et al., 2013). The low polymorphism found was taken to indicate that the genetic variability was small for the measured material, and that the RAPD primers used in the study showed low efficiency to recognize homologous DNA regions (Martínez et al., 2013).

Lorenzoni et al. (2014) studied the genetic diversity among accessions of Rollinia тисова using ISSR markers. They identified dissimilarity values ranging from 0.0909 to 0.5147 , showing high genetic diversity among the accessions. Thus, it can be inferred that the results of genetic dissimilarity in our study reflect a considerable genetic variability among the nanche accessions. This is justified by the fact that the evaluated nanche collection consisted of a small number of individuals.

Nanche is considered an allogamous and auto-compatible species (Sihag, 1995), although Pereira and Freitas (2002) observed low formation of fruits in flowers subjected to self-pollination. Our results reflect the genetic variability of the accessions studied, which highlights the importance of collecting more materials in the area represented in this study. Such an effort may identify genotypes with good prospect of commercial exploitation that can be used in genetic breeding programs.

Our results demonstrate the importance of using molecular markers for discrimination and identification of genetic materials. This makes it possible to quantify the genetic variability among individuals of the same species, even in species that are not considered domesticated and that have been little studied, as in the case of nanche. It also makes it possible to group genetically similar individuals. ISSR markers were efficient in detecting molecular polymorphisms in nanche. However, in future studies it will be necessary to expand the collection area, increase the number of prospected genotypes, and to include natural populations. It will then be possible to obtain information regarding the evolutionary and population mechanisms that may be used to decide on maintenance strategies and species conservation, particularly in the choice of individuals and areas to be sampled. Understanding the population dynamics of this understudied species could facilitate the choice of contrasting genotypes to be used in genetic breeding and in maintenance strategies. Such genetic information can be used together with morpho-agronomical information, in order to direct and accelerate the improvement of the species, in addition to making decisions about collecting new plant materials, conservation of the germplasm, and management of $B$. crassifolia genetic resources.

Genetics and Molecular Research 15 (4): gmr15048887 


\title{
Conflicts of interest
}

The authors declare no conflict of interest.

\section{ACKNOWLEDGMENTS}

\author{
We thank Dr. José Eduardo Urano for information about nanche collection of Embrapa \\ Eastern Amazon - PA. Research supported by Embrapa.

\section{REFERENCES}

Arrigoni-Blank MF, Santos MS, BlankAF, Rabbani AR, et al. (2016). Analysis of genetic diversity of Laeliinae (Orchidaceae) in the State of Sergipe using ISSR markers. Genet. Mol. Res. 15: http://dx.doi.org/10.4238/gmr.15027997.

Borém A and Miranda GV (2013). Melhoramento de Plantas. 6th ed. UFV, Viçosa.

Carvalho JEU and Nascimento WMO (2008). Caracterização dos pirênios e métodos para acelerar a germinação de sementes de muruci do clone Açu. Rev. Bras. Frutic. 30: 775-781. http://dx.doi.org/10.1590/S0100-29452008000300036

Carvalho JEU and Nascimento WMO (2013). Caracterização biométrica e respostas fisiológicas de diásporos de murucizeiro a tratamentos para superação da dormência. Rev. Bras. Frutic. 35: 704-712. http://dx.doi.org/10.1590/ $\underline{\mathrm{S} 0100-29452013000300006}$

Carvalho RS, Pinto JFN, Reis E, Santos SC, et al. (2012). Variabilidade genética de cajuzinho-do-cerrado (Anacardium humile St. Hill.) por meio de marcadores RAPD. Rev. Bras. Frutic. 34: 227-233. http://dx.doi.org/10.1590/S010029452012000100030

Cavalcante PB (2010). Frutas comestíveis na Amazônia. 7th ed. CNPq/Museu Paraense Emílio Goeldi, Belém.

Cruz CD and Carneiro PCS (2003). Modelos Biométricos Aplicados ao Melhoramento Genético. UFV, Viçosa.

Doyle JJ and Doyle JL (1990). Isolation of plant DNA from fresh tissue. Focus 12: 13-15.

Earl DA and VonHoldt BM (2012). STRUCTURE HARVESTER: a website and program for visualizing STRUCTURE output and implementing the Evanno method. Conserv. Genet. Resour. 4: 359-361. http://dx.doi.org/10.1007/s12686$\underline{011-9548-7}$

Evanno G, Regnaut S and Goudet J (2005). Detecting the number of clusters of individuals using the software STRUCTURE: a simulation study. Mol. Ecol. 14: 2611-2620. http://dx.doi.org/10.1111/j.1365-294X.2005.02553.x

Faleiro FG (2007). Marcadores genéticos moleculares aplicados a programas de conservação e uso de recursos genéticos, Embrapa Cerrados, Planaltina.

Ferreira ME and Grattapaglia D (1998). Introdução ao uso de marcadores moleculares em análise genética. 3rd ed. Embrapa, Brasília.

Ghariani S, Elazreg H, Chtourou-Ghorbel N, Chakroun M, et al. (2015). Genetic diversity analysis in Tunisian perennial ryegrass germplasm as estimated by RAPD, ISSR, and morpho-agronomical markers. Genet. Mol. Res. 14: 1852318533. http://dx.doi.org/10.4238/2015.December.23.40

Hammer Ø, Harper DAT and Ryan PD (2001). PAST: paleontological statistics software package for education and data analysis. Paleontol. Electron. 4: 1-9.

Lorenzoni RM, Soares TCB, Santiago VF, Silva JA, et al. (2014). Utilização de marcadores ISSR na avaliação da divergência genética entre acessos de biribazeiro. Rev. Bras. Frutic. 36: 251-257. http://dx.doi.org/10.1590/S0100$\underline{29452014000500029}$

Martínez ME, Lesher JM, Castañón N, de la Cruz L, et al. (2013). Genetic variability of nanche in Tabasco, Mexico, determined with RAPDs. Int. J. Exp. Bot 82: 209-214.

Patto MCV, Satovic Z, Pêgo S and Fevereiro P (2004). Assessing the genetic diversity of Portuguese maize germplasm using microsatellite markers. Euphytica 137: 63-72. http://dx.doi.org/10.1023/B:EUPH.0000040503.48448.97

Pepineli AC, Strioto DK, Marinelli GC, Mangolin CA, et al. (2014). Seleção de primers para análise de inter simple sequence repeats na cultivar 'itália' de Vitis vinifera L. Technical note. Cienc. Tec. Vitivinic. 29: 81-87.

Pereira JOP and Freitas BM (2002). Estudo da biologia floral e requerimentos de polinização do murucizeiro (Byrsonima crassifolia L.). Rev. Cienc. Agron. 33: 5-12.

Pessoni LA (2007). Estratégias de análise da diversidade em germoplasma de cajueiro (Anacardium spp. L.). Doctoral Thesis Programa de Pós-Graduação em Genética e Melhoramento, Universidade Federal de Viçosa, Viçosa.

Pritchard JK, Stephens M and Donnelly P (2000). Inference of population structure using multilocus genotype data. Genetics 155: 945-959.

Genetics and Molecular Research 15 (4): gmr15048887 
Rivas LH, Giustina LD, Luz LN, Karsburg IV, et al. (2013). Genetic diversity in natural populations of Theobroma subincanum Mart. in the Brazilian Amazon. Genet. Mol. Res. 12: 4998-5006. http://dx.doi.org/10.4238/2013. October.24.12

Rossi FS, Rossi AAB, Dardengo JFE, Brauwers LR, et al. (2014). Diversidade genética em populações naturais de Mauritia flexuosa L. f. (Arecaceae) com uso de marcadores ISSR. Sci. Forum 42: 631-639.

Shen XL, Zhang YM, Xue JY, Li MM, et al. (2016). Analysis of genetic diversity of Brassica rapa var. chinensis using ISSR markers and development of SCAR marker specific for Fragrant Bok Choy, a product of geographic indication. Genet. Mol. Res. 15: http://dx.doi.org/10.4238/gmr.15027557.

Sihag RC (1995). Pollination, pollinators and pollination modes: ecological and economic importance. In: Pollination of cultivated plants in the tropics (Roubik DW, ed.). FAO Agricultural Services Bulletin, Rome, 11-39.

Silva AVC, Freire KCS, Lédo AS and Rabbani ARC (2014). Diversity and genetic structure of jenipapo (Genipa americana L.) Brazilian accessions. Sci. Agric. 71: 387-393. http://dx.doi.org/10.1590/0103-9016-2014-0038

Silva EM, Souza JNS, Rogez H, Rees JF, et al. (2007). Antioxidant activities and polyphenolic contents of fifteen selected plant species from the Amazonian region. Food Chem. 101: 1012-1018. http://dx.doi.org/10.1016/j. foodchem.2006.02.055

Sokal RR and Rohlf FJ (1962). The comparison of dendrograms by objective methods. Taxon 11: 30-40. http://dx.doi. org $/ 10.2307 / 1217208$

Souza IG, Souza VA and Lima PS (2013). Molecular characterization of Platonia insignis Mart. ("bacurizeiro") using inter simple sequence repeat (ISSR) markers. Mol. Biol. Rep. 40: 3835-3845. http://dx.doi.org/10.1007/s11033-012-2462-6

Souza JNS, Silva EM, Loir A, Rees JF, et al. (2008). Antioxidant capacity of four polyphenol-rich Amazonian plant extracts: A correlation study using chemical and biological in vitro assays. Food Chem. 106: 331-339. http://dx.doi. org/10.1016/j.foodchem.2007.05.011

Genetics and Molecular Research 15 (4): gmr15048887 